\title{
How Good Is Good News? Technology Depth, Book-to-Market Ratio, and Innovative Events *
}

\author{
Qiao Liu ${ }^{\dagger}$
}

This Draft: May 2004

\begin{abstract}
This paper examines the stock market reactions to US biotech firms' innovation news announcements during 1983-1993. Besides the positive abnormal returns observed during the announcement period, the paper identifies a medium-horizon negative drift in the stock price subsequent to firms' innovative events. The observed negative drift is robust to the benchmarks and procedures used in calculating the abnormal returns. Cross-sectional analysis demonstrates that the post-announcement abnormal returns are positively related to a firm's technology depth (measured by R\&D intensity) and book-to-market ratio, negatively related to the size. The evidence favors the investors' expectational error hypothesis and supports the view that $R \& D$ or other intangibles are market value relevant in the high-tech industry.
\end{abstract}

JEL Classification: G12, G14, G24, G34

Keywords: innovative events, abnormal returns, technology depth, book-to-market ratio, value relevance of intangibles

${ }^{*}$ This is based on Chapter 2 of my UCLA dissertation. A major revision was completed while I was affiliated with McKinsey \& Company. I would like to thank the many members of McKinsey \& Company for sharing with me their insights about biotechnology and the biotechnology industry. I am grateful to Bradford Cornell, Michael Darby, David Levine, Hongbin Cai, seminar participants at UCLA, and participants at the 2001 FMA annual meeting for many constructive comments. Special thanks to Michael Darby and Lynne Zucker for generously providing me with the list of biotech firms used in this study. I gratefully acknowledge the contribution of the I/B/E/S International Inc. for the earnings forecast data. I appreciate the financial support of the HKU Research Initiation Grant and the RGC Earmarked Research Grant (HKU 7128/01H). All errors, of course, are my own.

${ }^{\dagger}$ Corresponding author. Mailing address: School of Economics and Finance, Faculty of Business and Economics, University of Hong Kong, Pokfulam Road, Hong Kong. Phone: (852)2859-1059. Fax: (852)25481152. E-mail: qliu@hku.hk. 


\title{
How Good Is Good News? Technology Depth, Book-to-Market Ratio, and Innovative Events
}

\begin{abstract}
This paper examines the stock market reactions to US biotech firms' innovation news announcements during 1983-1993. Besides the positive abnormal returns observed during the announcement period, the paper identifies a medium-horizon negative drift in the stock price subsequent to firms' innovative events. The observed negative drift is robust to the benchmarks and procedures used in calculating the abnormal returns. Cross-sectional analysis demonstrates that the post-announcement abnormal returns are positively related to a firm's technology depth (measured by R\&D intensity) and book-to-market ratio, negatively related to the size. The evidence favors the investors' expectational error hypothesis and supports the view that $R \& D$ or other intangibles are market value relevant in the high-tech industry.
\end{abstract}

JEL Classification: G12, G14, G24, G34

Keywords: innovative events, abnormal returns, technology depth, book-to-market ratio, value relevance of intangibles 


\section{Introduction}

In their Journal of Finance article, Huberman and Regev (2001) describe vividly the EntreMed saga: a Sunday New York Times article on a potential development of new cancercuring drugs caused the stock price of EntreMed to rise from 12.063 at the Friday close, to open at 85 and close near 52 on Monday; intriguingly, the breakthrough had been reported in the journal Nature and various newspapers including the Times (not on the front page though) five months earlier and no new information was presented in that Sunday Times article. Several puzzling questions immediately arise from the EntreMed drama - can investors rationally react to innovation news which has highly unpredictable economic value? If not, can they at least better price the innovations made by the firms with strong presence of technology knowhow ${ }^{1}$

This paper aims at addressing those questions by investigating investors' reactions to innovation news announcements in the biotechnology industry. Biotechnology is the set of techniques that use living organisms to make biologic products(e.g., drugs, modified foods), to assist in the development of non-biological products (e.g., specialty chemicals), or to research the basis of disease. The biotechnology industry is one of few industries that has purely emerged from several key innovative ideas and scientific breakthroughs — the double helix structure of DNA identified by Watson and Crick in the 1950s; restriction enzymes used to splice human DNA into microbes developed in the 1970s; and recombinant insulin approved for human use in the 1980s, etc. It is an ideal testing ground for us to understand how investors respond to innovative events with highly uncertain commercial potentials.

Searching the Lexis/Nexis database, we collect a sample of 611 innovation events announced by 103 biotech companies between January 1983 and December 1993. ${ }^{2}$ Applying

\footnotetext{
${ }^{1}$ Note that prior literature (e.g., Lev and Sougiannis 1996; Amir and Lev 1996; and Aboody and Lev 1998) has documented the value relevance of the intangibles in high-tech industries and argued that they contain information not captured by reported earnings and book values.

${ }^{2}$ The 1980s witnessed the majority of essential innovations in biotechnology. It was also a period during which the majority of biotech firms went public and scaled up their operations. Beginning in the mid 1990s, almost all major pharmaceutical players started to adopt enabling technologies which greatly blurred the line between biotech firms and pharmaceutical firms. To have a clean environment to conduct our analysis,
} 
the conventional event study method, we find that the average abnormal return to the announcements runs as high as $3.98 \%$ for a three-day event window. Austin (1993), and Chan et al. (1997) report similar findings in related settings.

But how well does the market interpret the news? Do the significantly positive abnormal returns imply that the good news really is that good? We then study the medium-term stock performance subsequent to innovative events. ${ }^{3}$ Following Barber and Lyon (1997), we use an appropriately selected single matched firm for each sample firm. We then calculate the stock returns of each sample firm net of the returns of its control firm. The exercise yields a striking result - in several months after the innovative events, negative drift in stock prices is observed and the average 3 -month post-announcement abnormal return is $-2.73 \%$. As a robustness check, we also use other benchmarks to measure the post-announcement medium-horizon stock performance. For example, we measure the medium-horizon stock performance adjusting for size and book-to-market effects; we also calculate the returns net of the returns of the industry portfolio comprised by firms with the same 4-digit SIC code; and lastly we employ the Fama-French 3-factor model to calculate the abnormal returns. All experiments yield the same result — the average post-announcement abnormal returns are significantly negative.

Our findings favor the investors' expectational error hypothesis. ${ }^{4}$ Namely, the investors are too easily seduced by prospects delivered by technological innovation news and tend to mis-price innovative events. Obviously, if this hypothesis is true, we expect that the degree of mispricing should not be universally symmetric — the mispricing should be more severe for the past winners (measured by low book-to-market ratio), and firms with a weak science and technology base (measured by the R\&D intensity). As event time passes and more information is revealed, investors start to gradually adjust the stock price to its appropriate we focus on the 1983-1993 period.

${ }^{3} \mathrm{~A}$ typical biotech firm makes innovation announcements on a frequent basis, the more common longhorizon (3 years or 5 years) stock performance approach is not necessarily applicable here.

${ }^{4}$ The same hypothesis has been used by La Porta et al. (1997) to explain the difference in value and glamour stocks in earnings announcement returns. 
level. The firms that were mispriced most in the beginning will adjust the most. Thus, we would observe that the stocks with a lower B/M ratio (glamour stocks), and the stocks of firms that are not R\&D intensive have larger medium-horizon negative drift. The analysis of the cross-sectional abnormal returns confirms the hypothesis. Note that the stocks of R\&D intensive firms performing better than other firms provides strong support for the R\&D value relevance argument (e.g., Lev and Sougiannis (1996)).

The paper relates to two streams of literature. The first one focuses on the valuation of R\&D ventures or firm-specific intangibles. Griliches (1981) is one of the first papers that studies the relationship between a firm's market value and its R\&D expenditures and patents, where Tobin's Q is used as the measure of the firm value and regressed against R\&D and patent counts. ${ }^{5}$ Darby, Liu, and Zucker (2004) propose a jump-diffusion process to capture the evolving of high-tech firms' valued assets. They identify the jumps in biotech firms' market value, which are caused by technological innovations. Event study approach has also been used to measure the value of technological innovations in prior literature (e.g., Austin 1993, and Chan et al. 1997). Event study, however, assumes that information contained in innovation news is revealed and incorporated into stock prices immediately. Our findings seriously challenge this assumption.

This paper also contributes to a large and growing literature that addresses the stock market reactions to different corporate events. A common finding in this literature is that the market does not respond completely to corporate events. Stock prices either overreact or under react to the firm's news announcements. ${ }^{6}$ In terms of the signs of announcement period abnormal returns, pre-and post-event abnormal returns, Dharan and Ikenberry (1995) is the closest one to our study. Both papers identify positive pre-event and announcement-period abnormal returns, and negative post-event abnormal returns. Dharan and Ikenberry argue

\footnotetext{
${ }^{5}$ Also see Megna and Klock 1993, Trajtenberg 1990, and Hall 1993.

${ }^{6}$ For example, Loughran and Ritter (1995) identify long-run negative abnormal returns subsequent to IPOs and SEOs; Dharan and Ikenberry (1995) find negative drift in stock prices after the firm is listed in a new exchange. Womack (1996) documents post-event positive abnormal returns subsequent to brokerage analysts' buy recommendations.
} 
that firms list their stocks to take advantage of the market's overreaction to their recent good times. This paper however shows evidence supporting the investors' expectational error hypothesis.

The remainder of the paper is organized as follows. In Section 2, we discuss the data used in this study. The stock market reactions to innovation-news announcements are studied in Section 3. We carry out the cross-sectional analysis of the short-and medium-horizon stock performance and link the degree of mispricing to several firm-specific variables in Section 4 . Section 5 concludes the paper.

\section{The Data}

To perform our search for the biotech firms' innovation-news announcements, we look for five categories of news announcements:

- FDA approval, which includes two possibilities: (i) a drug is approved for production or marketing; and (ii) a drug is approved to enter into clinical trials or the next round of trials.

- A patent is granted by the US Patent and Trademark Office.

- Scientific breakthroughs made by the firm's affiliated scientists. They are usually announced by the firm's scientists in professional conferences or published in top journals. Sometimes the firm even holds a press conference to announce its important discovery.

- Strategic alliances or research joint ventures formed by biotech firms.

- Others, e.g., news on technology transfer, news regarding research grants.

We find that the five categories of news announcements cover almost all of the biotech firms' technology-related news events. To obtain our sample, we start with 156 biotechnology 
companies that went public before $1993 .{ }^{7}$ We exclude the firms that do not have records in COMPUSTAT or CRSP. This reduces the number of biotech firms to 129. We then search the Lexis/Nexis database (including the Business Wire, PR Newswire, Southwest Newswire, Reuters and United Press International ) for the entire 1983-1993 period. We focus on 19831993 for the following reasons: (i) since the mid-1990s, most major pharmaceutical firms started to adopt enabling technologies, which blurred the line between pharmaceutical firms and biotech firms; (ii) teaming up with major pharmaceutical players has emerged as a popular business model for most biotech firms after 1994. As our purpose is to study how investors react to innovative ideas with highly uncertain commercial potential, we need a relatively clean environment.

To perform the search, we retrieve all the news released by the biotech firms. In order to isolate the effects of different events, we drop the innovation news that clusters with other news within a 10-month time period (5 months prior to and after). We then exclude the non-technology-related news items. We are able to identify 677 non-clustered technology events announced by 118 biotech firms. We drop the announcements made in the fourth quarter of 1987 to control the effects of the market crash on our empirical results. We also drop the announcements that lack complete data in the CRSP daily, or monthly return files. Finally, we are left with 611 announcements by 103 firms.

Panel A of Table 1 presents six sample announcements for the five categories defined above (there are two sample announcements for type 5). Panel B presents the number and percentage for each category in the whole sample. As shown in Table 1, the largest category in our sample is FDA approval, which accounts for $25.7 \%$ of total announcements. The second largest group turns out to be scientific breakthrough, which accounts for almost 24.1\%. Patent grant is ranked as the third with $20.1 \%$, and strategic alliance the fourth with 18.3\%. We identified 72 type- 5 announcements, which comprise about $11.8 \%$ of the sample.

\footnotetext{
${ }^{7}$ Special thanks to Michael Darby and Lynne Zucker for providing us with the list of biotech firms in the U.S. For the detail about the list, see Zucker et al. 1994.
} 
In order to measure the stock market's reaction, we use daily stock returns and monthly stock returns in our analysis, which are extracted from CRSP. Biotech firms' accounting information is from COMPUSTAT. The firms' IPO information is obtained from the Securities Data Corporation (SDC) files and financial analyst information is from the I/B/E/S database. Finally, in our analysis, we also use the reputation rank for the lead underwriters that brought the biotech firms public and this is obtained from Carter, Dark and Singh (1998).

\section{Stock Market Reactions to Innovative News Events}

\subsection{The announcement period stock performance}

Following the standard practice, we use the capital asset pricing model (CAPM) to estimate the effect of an innovation news announcement on stock returns. The factor loadings are estimated by using daily returns from trading day -120 to day -20 and from trading day 20 to day 130 relative to the announcement day. We designate day 0 the date that the firm makes the announcement. The coefficients are then used to calculate predicted returns. The difference between the actual and predicted returns is abnormal returns (ARs).

Table 2 summarizes the short-run stock price reaction towards innovation news announcements. We identify the abnormal returns up to 10 days prior to the event and 10 days after the event. We also calculate the cumulative abnormal returns for the 2-day event window (from day 0 to day 1 ), 3 -day event window (from day -1 to day +1 ) and 5 -day event window (from day -2 to day +2 ). Significance tests are based on a standardized test statistic constructed to determine whether the mean abnormal return is significantly different from zero. Panel A of Table 2 documents the abnormal returns from day -10 to day +10 . The day 0 average abnormal return is a statistically significant $2.977 \%(t-$ statistic $=7.99)$. Surprisingly, we find the average abnormal returns become negative after day 1 and are statistically significant on some of the days from day 2 to day 10. This imposes a serious 
challenge to the "information content" hypothesis since people may argue that the positive abnormal returns are caused by the buying pressure during the announcement period. After this pressure is gone, the stock price will revert to its initial level. ${ }^{8}$ In order to test whether this argument is sensible, we calculate the CARs from day +2 to day 11 (a rather long period for the buying pressures to evaporate). We find that the mean CARs for this period is just $-2.0 \%$, which is significantly lower than the returns at the announcement. Obviously, the innovation news contains information.

Panel B of Table 2 reports the CARs for three different event windows. Since our announcement dates come from the wire services and are not from the Wall Street Journal (WSJ), ${ }^{9}$ it is not surprising to find that most of the price adjustment in our sample occurs on the 5 days surrounding the announcements (from day -2 to day 2). As reported in Panel $\mathrm{B}$ of Table II, the average 3-day CARs is $3.978 \%$ and the average 2-day CARs is $3.573 \%$. Both are statistically significant (t-statistics are 7.97 and 7.57, respectively). The average 5-day CARs is $3.451 \%$ (t-statistic $=6.44)$. If we assume that the market incorporates the new information into the price efficiently and immediately, the above finding represents a very large amount of wealth increased due to the biotech firms' innovation activities.

In Panel $\mathrm{C}$ of Table 2, we analyze the average CARs for different innovative categories. Not surprisingly, all of them are significantly positive. Among five different categories, scientific breakthrough and FDA approval have the highest average CARs (the average 2day CARs are $5.54 \%$ and $4.79 \%$, respectively). The mean CARs of patent grant is $2.72 \%$, which is also higher than the level documented by Austin (1993). ${ }^{10}$ Both 2-day and 3-day CARs for patent grant are smaller than those of scientific breakthrough and FDA approval.

\footnotetext{
${ }^{8}$ For example, Barber and Loeffler (1993) conclude that the positive abnormal returns on recommendations by the Wall Street Journal "Dartboard Column" partly result from naive buying pressures.

${ }^{9}$ The Wall Street Journal normally has one day or two days' delay in its announcements of given events. Relying on the dates from the WSJ may misspecify the correct time of information disclosure. In that case, a longer window is appropriate, even though it may contain much noise.

${ }^{10}$ Our explanation is that Austin used patent grant dates from the US Patent Office as the event dates. In contrast, we obtain the event dates by searching the wire services, therefore, our events dates are more appropriate. Also, if a firm makes an announcement about a certain patent, this patent, everything else equal, should be relatively more valuable.
} 
Given the fact that about $70 \%$ of patent applications are eventually granted by the US Patent Office, we know that just before the patent is granted, the stock price should have included the expected value of the patent. The grant of the patent increases the probability that the patent will be granted from a number around 0.7 to 1.0 , so the value of the patent is only about a third of the value of the underlying discovery, with two thirds already in stock prices. Strategic alliance announcements cause a relatively small stir in the market. This can be explained by the fact that they are normally related to the earliest stages of a firm's R\&D process. ${ }^{11}$

\subsection{The medium-horizon post-event stock performance}

Given the costly information required to correctly estimate the value of an innovative event, one may suspect that investors may fail to correctly price an innovation news item. Studying the medium-horizon post-event stock performance thus is necessary.

There has been much controversy on medium-horizon and long-term return anomaly studies. Fama (1998) argues that most long-term return anomalies are actually due to the methodologies used. Once the appropriate methodologies are employed, most of the anomalies will disappear. In the same article, he also points out that cumulative abnormal returns (CARs) pose fewer statistical problems. Barber and Lyon (1997) provide a comprehensive discussion of inference problems in the tests of long-term anomalies. They argue that the buy-and-hold abnormal returns (BHARs) do a better job than the CARs. Lyon et al. (1999) develop elaborate techniques to correct some of the inference problems of BHARs. ${ }^{12}$ Given this controversy, we use both a CAR and BHAR approach in this paper and find they generate similar results.

\footnotetext{
${ }^{11} \mathrm{We}$ only include in our sample the strategic alliances or joint ventures that are related to R\&D. We exclude the announcements on marketing arrangements or product distribution arrangements.

${ }^{12}$ Brav (1999) has recently pointed out that all existing methods for drawing inferences from BHARs, including those in Lyon et al. (1999) fail to correct fully for the correlation of returns across events not absorbed by the model used to adjust for expected returns. However, given the fact that the time period considered in our study is much shorter than other long-term return anomaly studies, this correlation concern is not severe.
} 
To measure the medium-horizon abnormal stock performance following innovation-news announcements, we first use the control firm approach. Barber and Lyon (1997) show that this approach compares favorably to other approaches in drawing statistically reliable inferences. In the analysis, we use size-and-industry matched control firms. ${ }^{13}$ We first select the CRSP-listed firms in the Fama-French drug industry (with SIC code 2830-2836). At every year-end, we rank these firms by market value of equity within each exchange group. For each observation in the sample, we choose the firm with the market value closest to the sample firm within the same exchange as the control firm. If at a certain time point, there were fewer than five firms within the exchange/industry group, we then pair the sample firm with whichever firm has the same two-digit industry code and the closest market value. This arrangement enables us to pair all of our sample firms with one control firm. We calculate CARs and BHARs using monthly returns. The t-statistics are calculated by using the crosssection of excess returns, computed by the difference between sample and matching firm returns.

In addition to the control firm approach, we also employ three other methods to calculate the medium-horizon abnormal returns, namely, the industry benchmark method, ${ }^{14}$ the size and $\mathrm{B} / \mathrm{M}$ ratio benchmark method, ${ }^{15}$ and the Fama-French three-factor approach. ${ }^{16}$

\footnotetext{
${ }^{13} \mathrm{We}$ also use size and book-to-market matched control firm approach and and find it does not change the results qualitatively. We choose to report the former.

${ }^{14}$ We calculate the returns net of the industry benchmark. The industry benchmark portfolios are defined based on 4-digit SIC codes. The firm in our sample is matched to a 4-digit industry portfolio according to the firm's reported 4-digit SIC code.

${ }^{15} \mathrm{We}$ calculate the returns net of the returns of the size and $\mathrm{B} / \mathrm{M}$ ratio matched portfolio. We form the 25 (5X5) size and B/M ratio portfolios by following the same procedures in Fama and French 1992, 1993.

${ }^{16}$ For each firm, the returns are modelled to be:

$$
R_{j, t}=R_{f, t}+\gamma_{0}+\gamma_{1}\left(R_{m, t}-R_{f, t}\right)+\gamma_{2} S M B_{t}+\gamma_{3} H M L_{t}+\epsilon_{t},
$$

where $\mathrm{t}$ is an event month index, $R_{j, t}$ is the raw return for firm $\mathrm{j}, R_{f, t}$ is the risk-free rate (monthly return on 3 -month treasury bills), $R_{m, t}$ is the value-weighted CRSP index, $S M B_{t}$ in the above equation is the return difference between a portfolio of small and a portfolio of large firms, and $H M L_{t}$ is the return difference between a portfolio of high $\mathrm{B} / \mathrm{M}$ firms and a portfolio of low $\mathrm{B} / \mathrm{M}$ firms. The factor loadings in this equation are estimated by using the monthly returns from month -5 to month -1 , and from month 1 to month 12 (month 0 represents the event month) (also see Womack 1996). After we obtain the factor loadings, we are able to calculate the expected returns for one stock based on the equation. The Fama-French three-factor adjusted abnormal returns are thus defined as the difference between the raw returns and the theoretical returns derived from the above equation.
} 
Table 3 documents the medium-horizon mean abnormal returns. Since the required variables in computing medium-horizon abnormal returns are not available for every firmevent observation, our sample size shrinks to 580. Let us first look at the abnormal returns adjusted by the size-and-industry matched control firm. The average 2-month pre-announcement BHARs (from month -2 to month -1) are statistically and economically significant $\left(\mathrm{BHAR}_{-2}=3.74 \%\right.$, t-statistic $\left.=2.45\right)$. It implies that there may exist certain "leakage" before the news is finally announced. This finding suggests that only considering the abnormal returns around the announcement day might be misleading.

Our interest, however, is in post-announcement stock performance. As shown in Table 3, the firm suffers negative post-announcement drift in its stock prices. The negative drift can be observed for various time windows. To check whether this post-announcement negative drift is due to the procedures or the benchmarks employed, we compute the medium-horizon abnormal returns in both CAR and BHAR terms and use the four different methods discussed above. We find that the identified negative drift is robust. For example, using the size-andindustry matched control firm as the benchmark to compute abnormal stock returns, we find that the mean three-and four-month post-announcement BHARs are $-2.73 \%$ and $-3.40 \%$ respectively. If we consider CARs, the average three-and four-month CARs subsequent to the announcement are $-4.38 \%($ t-statistic $=-2.75)$ and $-3.75 \%($ t-statistic $=-2.03)$. The magnitude and significance are very similar to the BHARs.

Barber and Lyon (1997) argue that long-term BHARs are positively skewed and inferences drawn from them may be biased. In our study, the time horizons (several months) considered are much shorter than those in other studies on the long-run stock performance. The bad inference problem due to skewness may not be severe. Also, Barber and Lyon demonstrate that the matched control firm approach (as we use in the paper) can better control the inference problem due to skewness. Therefore, we only report the conventional t-statistics in Table $3 .^{17}$

\footnotetext{
${ }^{17}$ Lyon et al. (1999) propose a bootstrapped application of the following equation which provides wellspecified test statistics: $t_{s a}=\sqrt{n}\left(S+\frac{1}{3} \hat{\gamma} S^{2}+\frac{1}{6 n} \hat{\gamma}\right)$, where $\hat{\gamma}$ is an estimate of the coefficient of skewness
} 
Also, note that the cross-sectional correlation problem is not very severe given that we have excluded the clustered news announcements and the time horizons are much shorter in

our study. This avoids overlapping periods of return calculation for the same firm. ${ }^{18}$ Given the fact that our results are robust to all these experiments, we believe the identified negative drift is not spurious. We also check whether this drift is due to outliers. It turns out that dropping outliers does not change the results qualitatively.

One may question whether the magnitude of post-event abnormal returns is different across the five news categories since there is often some specific sequence associated with the occurrence of these events - e.g., scientific breakthrough comes earlier than field trials, which are then followed by FDA approval. Therefore, pooling them may yield spurious results. We compute the medium-horizon abnormal returns for each news category and then use the Kruskal-Wallis statistics to test whether the 5 different event categories are taken from the same population. The results show that the null hypothesis cannot be rejected at any reasonable significance levels. ${ }^{19}$ Obviously, even though there is a specific sequence associated with different types of events, it has not been reflected in the market reaction.

\section{Why is good news not that good?}

\subsection{Discussion of Possible Explanations}

\subsubsection{IPO or SEO Underperformance}

One of the explanations for the negative medium-horizon abnormal returns is that they are due to the well-documented post-IPO or post-SEO return behavior. Given the fact that and $\sqrt{n} S$ is the conventional t statistic. We undertake the experiment and find the results do not change significantly.

${ }^{18} \mathrm{We}$ do not correct the interdependence of stock returns among event firms for the following reasons: (1) we use industry portfolios to calculate the abnormal returns, which already capture part of the crosscorrelation among event firms; (2) we only consider 3-6 months subsequent to news announcements. During a relatively shorter period (compared to the years), the probability of having multiple events is comparatively low, therefore, the correlation problem is less severe; (3) Fama (1998) points out that using CARs reduces the biases due to cross-sectional correlation.

${ }^{19}$ Not reported in the paper, but available upon request from the author. 
the biotech industry is a new industry and many biotech firms went public just recently, it is very likely that the observed negative drifts are caused by biotech firms' recent IPOs or SEOs.

In order to test the hypothesis, we decompose our sample into two groups: one that consists of firms that had an IPO or SEO within three years of the studied events; the other that consists of firms that had not had any IPO or SEO in these 3 years. We compute the medium-horizon post-announcement abnormal returns for both groups. The results are reported in Panel A of Table 4. Clearly, if we exclude the events for the firms that had had IPO or SEO within 3 years of the studied events (there are 128 such events), the medium-horizon BHARs of the remaining events are still significantly negative. For example, the 3-month BHARs for Non-IPO and Non-SEO firms are -8.43\% (t-statistic = -4.22). Interestingly, compared to Non-IPO and Non-SEO firms, IPO or SEO firms' postevent abnormal returns are, on average, smaller in their magnitude. This is in striking contrast with the IPO/SEO underperformance hypothesis. One of the possible explanations is that investors are more cautious about the innovation news issued by firms that had had IPO or SEO recently. If it is indeed the case, then it would be consistent with the investor expectational error hypothesis, which we will detail later.

\subsubsection{Mean-reversal in Stock Returns}

An alternative explanation for the observed post-event negative drift is that it is due to the mean-reversal of stock returns. According to this argument, although investors may have overreacted to the initial news, they adjust down the stock prices later. Several past studies have reported on such price reversals following large initial reactions (e.g., Barber and Loeffler 1993).

If the negative post-announcement abnormal returns are indeed caused by the price reversals, we would observe that the firm-event with large initial reactions has large postevent negative drift. Panel B of Table 4 provides the correlation table for the announcement period abnormal returns (ER0, ER3), pre-event BHARs $\left(B H A R_{-1}, B H A R_{-3}\right)$, and post- 
event BHARs $\left(B H A R_{1}, B H A R_{3}, B H A R_{4}\right)$. Clearly, the post-event abnormal returns are not significantly correlated to announcement period abnormal returns, and are unrelated to the pre-event abnormal returns.

\subsubsection{Survivor Bias}

Another confounding cause of medium-horizon negative returns is the survivor bias. In our sample selection process, we exclude the firm-event that lacks complete data in CRSP or COMPUSTAT databases. It is likely that successful biotech firms are bought out and therefore withdraw from the sample, leaving the less successful ones in the sample. To provide a robustness check, we re-examine our sample selection process. Among the 66 observations dropped from the sample due to a lack of data, 37 are dropped simply because they occurred in the fourth quarter of 1987 . We intentionally exclude them to control the effects of market crash on the stock returns. 29 firm-events are dropped because they contained missing values, among which only 7 firm-event observations are eliminated due to M\&A activities. Even if we assume that the acquired or merged firms are more successful than other firms (our conversations with the biotech experts show that it is not the case), their impact on the sample is very limited.

\subsubsection{Window of Opportunity Hypothesis}

Many studies attribute the abnormal long-run stock performance to the firm managers' timing ability. For example, Dharan and Ikenberry (1995) study negative post-listing abnormal returns and find that firm managers decide to change the exchange listing when their stocks are overvalued. Ritter (1991) also applies the same reasoning to explain the long-run IPO underperformance. If biotech firms' managers are timing their innovative news announcements, then we should expect a post-announcement negative drift in stock returns. Although this hypothesis seems promising, it has several problems. As we will show in Section 4.2, large firms or firms with low B/M ratio tend to have a large negative drift. This clearly runs against the window of opportunity hypothesis since small firms or firms with bad past market performance should have stronger incentive to time their announcements. 


\subsubsection{Investors' Expectational Error Hypothesis}

The negative post-event drift may also result from investors' expectational error. Given the fact that most innovations in high-tech industries are technologically complicated, investors may have trouble fully understanding these announcements. Innovation news per se is treated favorably. As event time proceeds, investors steadily liberate themselves from their initial enthusiasm. This learning process leads to a gradual adjustment over a relatively longer horizon in the stock returns. Obviously, this is a real question for future research as to how this over-optimism could form in the first place and appear repeatedly and predictably.

If this hypothesis is true, we should observe that the mispricing problem would not be universally symmetric across firms. For the firms that have a very strong past stock performance, and the firms that do not have much technology depth, the mispricing problem is more likely to be severe. Consequently, the medium-horizon post-announcement negative price drift should be larger. On the contrary, for the firms that have invested intensively in $\mathrm{R} \& \mathrm{D}$, and the firms that have been out of favor, mispricing becomes less likely. We are able to test the mispricing hypothesis by studying whether the above predictions hold empirically.

\subsection{Testing the Investors' Expectational Error Hypothesis}

In order to test the investors' expectational error hypothesis, we first introduce several firmspecific variables. First, it is important to capture the presence of a biotech firm's technology knowhow - its technology depth. We use R\&D intensity to do so. We first calculate the stock of $\mathrm{R} \& \mathrm{D}$ capital, $R D C_{j, t}$ for firm $\mathrm{j}$ in year $\mathrm{t}$ based on current and past $\mathrm{R} \& \mathrm{D}$ expenditures:

$$
R D C_{j, t}=R \& D_{j, t}+0.8 R D C_{j, t-1}
$$

In equation (1), we assume that the productivity of each dollar of $R \& D$ spending declines linearly by twenty percent a year. This assumption is consistent with other studies on R\&D. ${ }^{20}$ Chan, Lakonishok and Sougiannis (1999) apply the ratios of R\&D relative to sale and market

\footnotetext{
${ }^{20}$ For example, Chan, Lakonishok, and Sougiannis (1999).
} 
equity value to measure a firm's $R \& D$ intensity. The ratio of $R \& D$ capital (RDC) relative to sales is not an appropriate measure of $R \& D$ intensity in our study given the fact that many biotech firms do not have products in the marketplace. We measure a firm's R\&D intensity using the ratios of R\&D stock relative to total assets (book value), and market equity value. We name them $R \& D /$ asset and $R \& D /$ equity, respectively. Also, considering that in year $\mathrm{t}$, only the accounting information in year $\mathrm{t}-1$ is available, we use $R \& D /$ Asset $_{t-1}$ and $R \& D /$ equity $_{t-1}$ to capture the firm's technology depth in year t.

Like most studies on long-term stock performance, we are interested in the roles played by size and $\mathrm{B} / \mathrm{M}$ ratio. The size variable is defined as the natural $\log$ of market equity value. Also, we define a new variable, SIZERANK to capture the size quintile in the CRSP universe that the firm is in. For example, if the firm is in the top size quintile then SIZERANK $=5$; if it is in the bottom quintile, then SIZERANK=1.

We defined two book-to-market variables in our study: the natural $\log$ of $\mathrm{B} / \mathrm{M}$ ratio (LBM), and the rank of B/M (BMRANK) in the CRSP universe. The latter measures the book-to-market ratio quintile in which the firm is placed in the CRSP universe. That is, if the firm belongs to the top quintile, then the BMRANK is 5; and if it belongs to the bottom quintile, then the BMRANK is 1.

As argued by Carter, Dark, and Singh (1998), underwriters may play a role in reducing asymmetric information surrounding news announcements. The information asymmetry problem is less severe for the firms that were made public by underwriters with a good reputation. For each firm in our sample, we obtain the name of its lead underwriter from the SDC database. We denote the quality of the underwriters by using their relative reputational standing during 1985-1991. Lastly, we also use the age of the firm, and the time since IPO, and some other firm-specific variables to control the cross-sectional difference. 


\subsubsection{Cross-sectional analysis of announcement period abnormal returns}

We conduct the cross-sectional analysis of the announcement period returns and the mediumhorizon abnormal returns and report the results in Table 5 . The left half of Table 5 (models 1-4) reports the results of using either one-day abnormal returns, ER0, or three-day CARs, ER3, as the dependant variables. Note that both ER0 and ER3 are negatively correlated with the size variables — LME and SIZERANK. They are also negatively related to the underwriter reputation. We also observe a negative relationship between them and the B/M ratio, the relationship is not significant though. The most striking fact, however, is that both ER0 and ER3 are positively related to the firm's R\&D intensity, measured by either $R \& D /$ asset $_{t-1}$ or $R \& D /$ equity $_{t-1}$.

The evidence is not consistent with the buying pressure hypothesis since we observe that the short-run abnormal returns are related to variables that capture the degree of information asymmetry (e.g., size and underwriter reputation). The negative relation between ER0, ER3 and B/M ratio implies that the investors view more favorably the news

about firms that have had a good past stock performance and they are relatively concerned with the innovative events issued by firms with value stocks. The evidence suggests that the investors' estimation about the innovation could be biased. The economically and statistically significant correlation between the firm's R\&D intensity and the investors' initial response to the innovation highlights the importance of R\&D (or more generally, intangibles) in assessing the economic value of a certain innovation.

To sum up, the announcement period abnormal returns depend on how investors assesss the information contained in a certain item of innovation news. Their inferences strongly depend on the firm's technology depth, past stock performance, and size.

\subsubsection{Cross-sectional analysis of medium-horizon abnormal returns}

Since the market reactions may reflect investors' over-optimism about innovation news announcements, the investors will adjust their expectation about the value of the innovations 
once they realize that they may have been wrong in the first place or subsequent developments fail to meet their initial anticipations. If this investors' expectational error hypothesis is true, we expect the post-event negative drift to be related to several firm-specific variables that proxy for the degree of over-optimism at the announcements. We run the multivariate regressions using the medium-horizon abnormal returns as the dependent variables and report the results in the right half of Table 5 (models 5-8). ${ }^{21}$

The results from Table 5 are striking: after we control for the age of the firm or the time since IPO and the reputation rank of the firm's underwriter, we still find significant correlation between medium-horizon post-event abnormal returns and R\&D intensity, and $\mathrm{B} / \mathrm{M}$ ratio. The results strongly suggest that the $\mathrm{R} \& \mathrm{D}$ intensity and $\mathrm{B} / \mathrm{M}$ ratio could explain the medium-horizon negative abnormal returns. The size variables - LME and SIZERANK - enter the regressions positively although the relationship is not significant in most model specifications. The underwriter's reputation - MANAGER — is not significant, which implies that underwriter's reputation is not an important information variable in the medium and long run. In the medium and long run, the investors probably are able to use more reliable variables to retrieve the information contained in certain news. Also note that when we control for the firm age and the time since IPO, the results do not change. This implies that the observed anomaly is not due to the well-documented IPO underperformance. ${ }^{22}$ Below we discuss the key variables one by one to demonstrate how they support the investors' expectional error hypothesis:

\section{Technology Depth}

The positive sign of $R \& D$ intensity variables $-R \& D /$ equity $_{t-1}$ and $R \& D /$ asset $_{t-1}-$ implies that innovations made by the firms that have invested less intensively in R\&D are more likely to be overvalued in the beginning; as a result of this, the post-announcement

\footnotetext{
${ }^{21}$ Note we only report the results of using BHARs, which are calculated by netting the raw returns out of the returns of size-and-industry matched firms. Using other abnormal returns measures yields the same results.

${ }^{22}$ As one may suggest, the negative drift may be caused by bad news that immediately follows the initial good news. This seems unlikely in our study given the fact we drop the news clustering with other news. Also, in our search for technological news announcements, we do not see such a pattern.
} 
negative drift may be more severe for them. Obviously, the negative medium-horizon drift is mainly driven by the firms that have not been active in $R \& D$. This finding supports the investors' expectational error hypothesis. It is worth noting that the evidence on $\mathrm{R} \& \mathrm{D}$ also supports the R\&D value relevance argument (see Lev and Sougiannis 1996).

\section{Glamour vs. Value}

If investors misprice the value of innovations, the mispricing should be more severe for low B/M stocks (glamour stocks) since those stocks normally draw more attention and investors tend to extrapolate the past performance into the future. By the same logic, we expect stocks with high $\mathrm{B} / \mathrm{M}$ ratios (value stocks) to be less mispriced. The positive sign of the two bookto-market ratio variables in models 5-8 - LBM and BMRANK - confirms the argument. Obviously, as B/M ratio increases, the negative drift in stock returns becomes smaller. The evidence suggests that investors are systematically more responsive to the innovative events of glamour stocks. Medium-horizon negative performance subsequent to innovation news announcements thus may be partly explained by investors' initial over optimism towards innovative events of glamour stocks.

Small firms vs. large firms

The negative sign of size variables implies that small firms outperform large firms in the post-event period. The evidence is inconsistent with the window of opportunity hypothesis if the negative drift in stock prices subsequent to the innovation news is caused by managers' timing ability, it should be more severe for small firms and firms with bad past performance (value stocks) but not large and growth firms.

It is bewildering as to why larger firms have larger negative drift. One possibility is that the market mistakenly assumes that large firms will have a higher future probability of technological success whereas, in reality, they are no more likely to succeed in research than smaller firms. If it is true, we would expect the investors to be more optimistic about larger firms' innovative events. However, the announcement period returns are actually smaller for larger firms. 
Another explanation is as follows. Large firms usually attract more attention from investors. If investors overestimate the value of innovation news, the mispricing may be exaggerated since there are more tradings for such firms. Consequently, the medium-horizon post-event negative drift is more substantial for them. This explanation clearly is in line with the "investors' expectational error hypothesis".

\subsubsection{Further Evidence from Analyst Forecast Data}

The identified empirical evidence favors the investors' expectational error hypothesis. If the negative post-event abnormal returns are indeed caused by investors' expectational error, it will also be reflected in financial analysts' earnings forecasting activities. We search the I/B/E/S summary database for financial analysts following information. Among 580 firmevent observations, there are 347 which have at least one annual earnings forecast on the event month. 233 firm-event observations do not have any financial analyst following on the event month.

For the 347 firm events with analysts following, we sort them by their ex post forecast errors. Here, the ex post forecast errors are defined as the difference between the median of annual earning forecast issued on the event month minus the actual annual earnings realization deflated by the stock price at the end of the event month. We compare the postevent return behavior for top the 30\% observations (optimistic group) and the bottom $30 \%$ observations (pessimistic group). For the optimistic group, the subsequent developments fail to meet the analysts' expectation. Therefore, if the investors' expectational error hypothesis is correct, we should expect this group has larger post-announcement negative drift. Evidence from Table 6 confirms this argument. It seems that the post-announcement negative drift is largely driven by the group of firms towards which the analysts have been overly optimistic. 


\section{Conclusion}

This paper examines the stock market reactions to U.S. biotech firms' innovation news announcements. We identify a medium-horizon negative drift in the stock price subsequent to firms' innovative events and propose an expectational error hypothesis to explain the observed puzzle. Our basic argument is as follows. Since R\&D ventures in high-tech industries are multi-stage projects with many sources of risk, it is hard for investors or even managers to precisely evaluate the economic value of innovations from different stages. The investors' valuation process is a learning by doing process with the possibility of forming erroneous expectations. In the high-tech field, this expectational error could be reflected in the investors' over-optimism towards a high-tech firm's innovation news. The expectational error leads to investors' mispricing of innovative events. However, the degree of mispricing is not universally symmetric. The firms with a weak science and technology base, high B/M ratio, or of large size are more likely to be mispriced.

The identified empirical evidence and corresponding explanation generate several implications: (i) given the fact that investors tend to misprice the value of innovative events, using an event study approach to value a certain innovation is questionable; and (ii) a high-tech firm's stock market performance is eventually determined by the firm's

fundamentals, especially its technology depth. This suggests the possibility of using R\&D or other intangibles to explain cross-sectional difference in stock returns. 


\section{References}

[1] Aboody, D., and B. Lev, 1998, The value relevance of intangibles: the case of software capitalization, Journal of Accounting Research, 36(0): 161-191.

[2] Amir, E., and B. Lev, 1996, The value relevance of nonfinanical information: the wireless communication industry, Journal of Accounting and Economics, 22(1-3): 3-30.

[3] Austin, David, 1993, An Event-Study Approach to Measuring Innovative Output: The Case of Biotechnology, American Economic Review Vol. 83 No. 2: 253-258.

[4] Barber, B. and J. Lyon, 1997, Detecting Long-run Abnormal Stock Returns: The Empirical Power and Specification of Test Statistics, Journal of Financial Economics 43, 341-372.

[5] Barber, B. and D. Loeffler, 1993, The "Dartboard" Column: Second-hand Information and Price pressure, Journal of Financial and Quantitative Analysis, Vol.29, 273-284.

[6] Carter, Richard, Federick Dark, and Ajai K. Singh, 1998, Underwriter Reputation, Initial Returns, and the Long-term Performance of IPO stocks, Journal of Finance,285311.

[7] Chan, Louis K.C., Josef Lakonishok, and Theodore Sougiannis, 1999, The Stock Market Valuation of Research And Development Expenditures, NBER Working Paper W7223.

[8] Chan, Su Han, John W. Kensinger, Arthur J. Keown, and John Martin, 1997, Do Strategic Alliances Crate Value? Journal of Financial Economics 46, 199-221.

[9] Darby, Michael, Qiao Liu, and Lynne Zucker, 2004, High stakes in high-technology: high-tech market values as options, Economic Inquiry, Vol. 42, No.3, 351-369.

[10] Dharan, B., and D. Ikenberry, 1995, The Long-run Negative Drift of Post-listing Stock Returns, Journal of Finance 50: 1547-1574.

[11] Fama, E. and K. French, 1992, The cross-section of expected stock returns, Journal of Finance.

[12] Fama, E. and K. French, 1993, Common Risk Factors in the Returns on Stocks and Bonds, Journal of Financial Economics 33, 3-56.

[13] Fama, E., 1998, Market Efficiency, Long-term Returns and Behavioral Finance, Journal of Financial Economics 49, 283-306.

[14] Griliches, Zvi, 1981, Market Value, R\&D, and Patents, Economic Letter 7:183-187.

[15] Hall, Bronwyn H., 1993, The Stock Market Valuation of R\&D Investment during 1980s, American Economic Review 83: 259-264.

[16] Huberman, G., and T. Regev, 2001, Contagious speculation and a cure for cancer: a nonevent that made stock prices soar, Journal of Finance, Vol. LVI, No. 1: 387-396. 
[17] Jaffe, Adam, 1986, Technological Opportunity and Spillovers of R\&D: Evidence from Firms' Patents, Profits, and Market Value, American Economic Review 76, 984-1001.

[18] La Porta, R., J. Lakonishok, A. Shleifer and R. Vishny, 1997, Good News for Value Stocks: Further Evidence on Market Efficiency, Journal of Finance 50, 859-874.

[19] Lev, B., and T. Sougiannis, 1996, The capitalization, amortization, and value-relevance of R\&D, Journal of Accounting and Economics, 21, 107-138.

[20] Loughran, T. and J. Ritter, 1995, The New Issues Puzzle, Journal of Finance, 50,23-51.

[21] Lyon, John, B. Barber, and Chih-Ling Tsai, 1999, Holding Size While Improving Power in Tests of Long-run Abnormal Stock Returns, Journal of Finance, 165-201.

[22] Megna, Pamela, and Mark Klock, 1993, The Impact of Intangible Capital On Tobin's Q in Semiconductor Industry, American Economic Review 83: 265-269.

[23] Trajtenberg, Manuel, 1990, A Penny for Your Quotes: Patent Citations and the Value of Innovations, Rand Journal of Economics 21(1):172-187.

[24] Womack, K., 1996, Do Brokerage Analyst's Recommendations Have Investment Value? Journal of Finance 137-167.

[25] Zucker, Lynne G., Michael R. Darby, and M. Brewer, 1999, Intellectual human capital and the birth of U.S. biotechnology enterprises, American Economic Review, 88(1), 290-306. 
Table 1: Biotech firms' innovation news announcements: 1983-1993

Announcements were identified using a search of the Lexis/Nexis database (including the Business Wire, PR Newswire, Southwest Newswire, Reuters and United Press International) for the 1983-1993 period. We classify the announcements into 5 categories according to the nature of a given piece of news (1) FDA approval; (2) patent grant; (3) scientific breakthrough; (4) strategic alliance or joint venture; (5) announcements that cannot be classified into any of these 4 groups. Panel A of this table provides a sample announcement for the first 4 types of news and two sample announcements for the fifth category. Panel B presents the percent of each category in the sample.

Panel A: Sample announcement by category

\begin{tabular}{|c|c|}
\hline Announcement Category & Sample Announcement \\
\hline I. FDA approval & $\begin{array}{l}\text { The Food and Drug administration Friday approved Genentech's first human } \\
\text { pharmaceutical, a biosynthetic growth hormone for treating severely non- } \\
\text { growth children... (Business Wire, 10/18/85). }\end{array}$ \\
\hline II. Patent Grant & $\begin{array}{l}\text { Advanced Magnetics, Inc. (NASDAQ: ADMG) announced today that it has } \\
\text { been granted U.S. Patent 5,055,288 which includes claims to } \\
\text { superparamagnetic resonance contrast agents wit ha long blood half-life... (PR } \\
\text { Newswire, 10/01/91) }\end{array}$ \\
\hline $\begin{array}{l}\text { III. Scientific } \\
\text { Breakthrough }\end{array}$ & $\begin{array}{l}\text { Scientists at Genelabs Incorporated, in collaboration with the Hepatitis Branch } \\
\text { of the Centers for Disease Control (CDC), today reported in the journal Science } \\
\text { that they have successfully cloned a portion of the Hepatitis E Virus... This is } \\
\text { a very exciting discovery, which creates the possibility of a tool diagnosing the } \\
\text { illness... (PR Newswire, } 03 / 16 / 90) \text {. }\end{array}$ \\
\hline $\begin{array}{l}\text { IV. Strategic Alliance or } \\
\text { Joint Venture }\end{array}$ & $\begin{array}{l}\text { Agouron Pharmaceuticals, Inc. announced today that it has formed a major } \\
\text { strategic alliance with Japan Tobacco Inc., of Tokyo, for the joint discovery, } \\
\text { development and commercialization of novel therapeutic drugs which act on } \\
\text { key proteins related to the human immune systems...(PR Newswire, 12/18/92). }\end{array}$ \\
\hline V. Others & $\begin{array}{l}\text { Advanced Genetic Sciences announced Wednesday the company successfully } \\
\text { completed its second field-test of Frostban, the genetically altered bacteria } \\
\text { designed to prevent frost damage to fruit and nut crops. Preliminary results } \\
\text { confirmed that Frostban effectively protected strawberry plants from the } \\
\text { natural bacteria that cause frost to form... (Business Wire, 04/27/88). }\end{array}$ \\
\hline & $\begin{array}{l}\text { Biogen, Inc. announced today the beginning of clinical trials for RECEPTIN, } \\
\text { its brand of recombinant soluble CD } 4 \text {, an experimental AIDs therapeutic... } \\
\text { (PR Newswire, 10/12/88). }\end{array}$ \\
\hline \multicolumn{2}{|c|}{ Panel B: Description of the sample by Category } \\
\hline Category of Announcements & s Number of Announcements \\
\hline I. FDA Approval & 25.7 \\
\hline II. Patent Grant & 20.1 \\
\hline III. Scientific breakthrough & 24.1 \\
\hline IV. Strategic Alliance & 18.3 \\
\hline V. Others & 11.8 \\
\hline Total & 100 \\
\hline
\end{tabular}


Table 2: Abnormal returns(ARs), and cumulative abnormal returns(CARs) around news announcements

The sample is 611 innovation news announcements made by 103 biotech companies between 1983 and 1993. The abnormal returns (ARs) are derived from the capital asset pricing model (CAPM) using the CRSP value-weighted market index as the market return. Besides abnormal returns, we also calculate the cumulative abnormal returns (CARs) for 2-day period, 3-day period and 5-day period, t-statistics are calculated from the cross section of abnormal returns or cumulative returns.

Panel A: Abnormal stock returns around the announcement day

\begin{tabular}{lll}
\hline $\begin{array}{l}\text { Day from } \\
\text { Distribution }\end{array}$ & AR & t-statistic \\
\hline Day -10 & $0.179 \%$ & 0.92 \\
Day -9 & $0.141 \%$ & 0.77 \\
Day -8 & $-0.178 \%$ & -0.98 \\
Day -7 & $0.277 \%$ & 1.47 \\
Day -6 & $-0.087 \%$ & -0.42 \\
Day -5 & $0.160 \%$ & 0.81 \\
Day -4 & $0.136 \%$ & 0.74 \\
Day -3 & $-0.074 \%$ & -0.41 \\
Day -2 & $0.272 \%$ & 1.41 \\
Day -1 & $0.404 \%$ & 1.92 \\
Day 0 & $2.977 \%$ & 7.99 \\
Day 1 & $0.596 \%$ & 2.34 \\
Day 2 & $-0.798 \%$ & -3.97 \\
Day 3 & $-0.276 \%$ & -1.40 \\
Day 4 & $-0.163 \%$ & -0.94 \\
Day 5 & $-0.381 \%$ & -1.87 \\
Day 6 & $-0.097 \%$ & -0.54 \\
Day 7 & $-0.379 \%$ & -1.93 \\
Day 8 & $-0.455 \%$ & -2.40 \\
Day 9 & $-0.385 \%$ & -1.97 \\
Day 10 & $-0.018 \%$ & -0.09 \\
\hline
\end{tabular}

Panel B: Cumulative Abnormal Returns $(\mathrm{N}=611)$

\begin{tabular}{lll}
\hline & CAR & t-statistic \\
\hline 3-day event ( $t$-1 to $t+1)$ & $3.978 \%$ & 7.97 \\
2-day event ( $t$ to $t+1)$ & $3.573 \%$ & 7.57 \\
5-day event ( $\mathrm{t}-2$ to $\mathrm{t}+2)$ & $3.451 \%$ & 6.44 \\
\hline
\end{tabular}

Panel C: Cumulative abnormal Returns by Category

\begin{tabular}{|c|c|c|c|c|c|c|}
\hline & \multicolumn{2}{|c|}{2 day event window } & \multicolumn{2}{|c|}{$\underline{3 \text { day event window }}$} & \multicolumn{2}{|c|}{$\underline{5 \text { day event window }}$} \\
\hline & CAR & t-statistic & CAR & t-statistic & CAR & t-statistic \\
\hline $\begin{array}{l}\text { I. FDA Approval } \\
\qquad(\mathrm{N}=157)\end{array}$ & $4.796 \%$ & 5.75 & $4.970 \%$ & 5.49 & $4.811 \%$ & 4.872 \\
\hline $\begin{array}{l}\text { II. Patent Grant } \\
\qquad(\mathrm{N}=123)\end{array}$ & $2.727 \%$ & 3.06 & $2.222 \%$ & 2.45 & $2.281 \%$ & 2.308 \\
\hline $\begin{array}{l}\text { III. Scientific breakthrough } \\
\qquad(\mathrm{N}=147)\end{array}$ & $5.554 \%$ & 4.37 & $6.481 \%$ & 4.72 & $5.718 \%$ & 3.841 \\
\hline $\begin{array}{l}\text { IV. Strategic Alliance } \\
\qquad(\mathrm{N}=112)\end{array}$ & $1.879 \%$ & 1.84 & $2.069 \%$ & 4.72 & $1.355 \%$ & 1.87 \\
\hline $\begin{array}{l}\text { V. Others } \\
\qquad(\mathrm{N}=72)\end{array}$ & $0.977 \%$ & 2.53 & $2.671 \%$ & 2.11 & $2.618 \%$ & 2.616 \\
\hline
\end{tabular}




\section{Table 3: Medium-Horizon Mean Abnormal Returns (in percent) Using Alternative Benchmarks}

Panel A documents the buy-and-hold abnormal returns several months before the announcements and after the announcements. Panel B documents the CARs. For all cases, the event month is the calendar month in which the announcement occurs. We use four different benchmarks to calculate the abnormal returns: size-and-industry matched firm, 4-Digit SIC industry portfolio, size and book-to-market matched portfolio, and Fama-French 3-factor model based portfolio. Note that t-statistics are used to test the hypothesis that there is no medium horizon abnormal returns, and are cross-sectionally calculated.

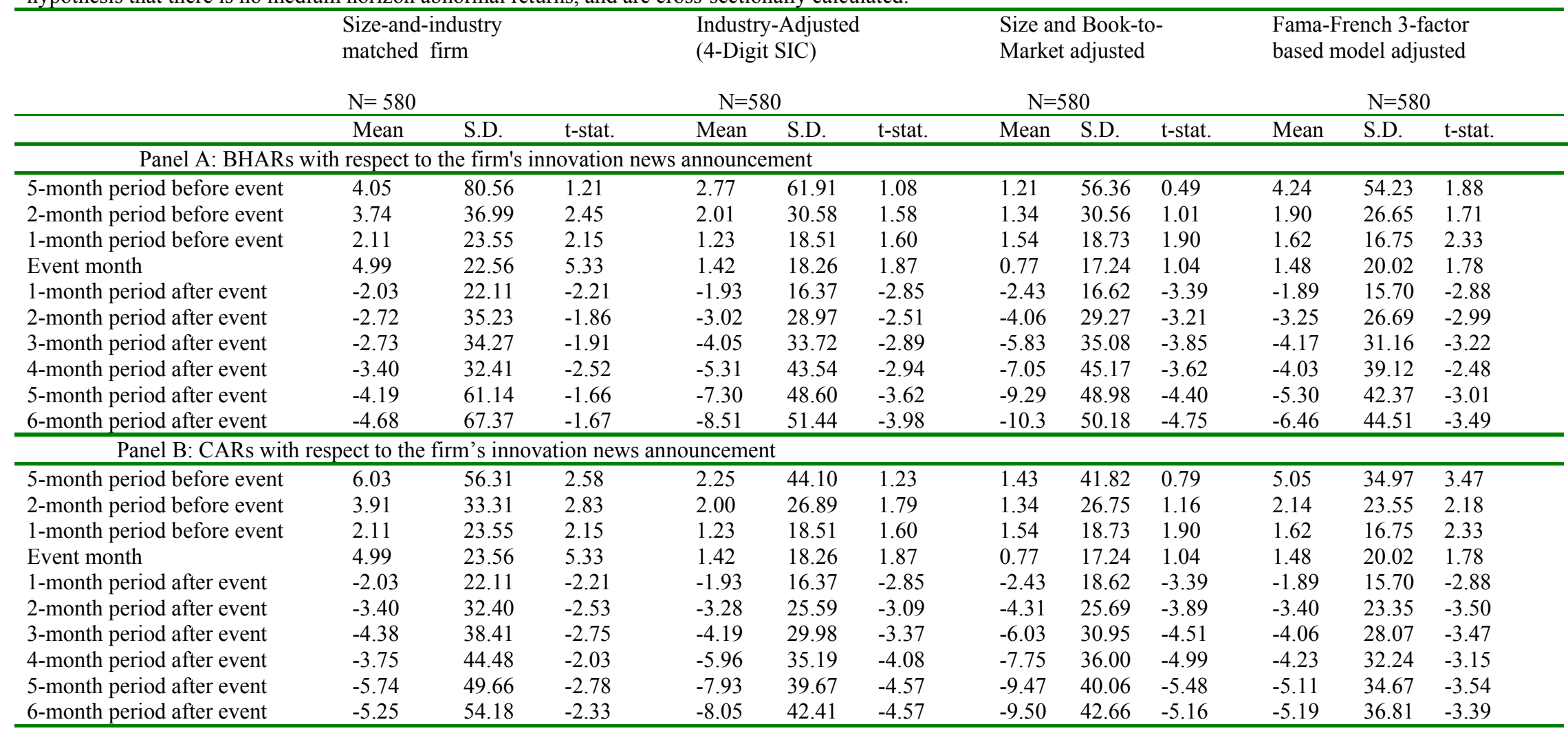


Table 4 Test of Several Competing Hypotheses

\section{Panel A: Medium-horizon BHARs for IPO or SEO firms and Non-IPO and Non-SEO firms}

Panel A reports the post-announcement buy-and-hold abnormal returns (adjusted by the returns of size and book-to-market ratio matched portfolios) for two different sub samples: 1. the firms that had had IPO or SEO within three years of the studied events (IPO or SEO firms); 2. the firms that had not had any IPO or SEO within three years (Non-IPO and Non-SEO firms). The abnormal returns are reported in percent. tstatistics are reported in parenthesis.

\begin{tabular}{llll}
\hline & $\begin{array}{l}\text { IPO or SEO firms } \\
(\mathrm{N}=128)\end{array}$ & $\begin{array}{l}\text { Non-IPO and Non-SEO firms } \\
(\mathrm{N}=452)\end{array}$ \\
\hline 1-month BHARs after event & -2.22 & $(-1.22)$ & $-2.47(-3.16)$ \\
2-month BHARs after event & -3.29 & $(-2.51)$ & $-4.83(-2.53)$ \\
3-month BHARs after event & $-3.46 \quad(-1.92)$ & $-8.43(-4.22)$ \\
6-month BHARs after event & $-6.78 \quad(-2.04)$ & $-13.1(-5.04)$ \\
\hline
\end{tabular}

Panel B: Association between announcement period returns and medium-horizon returns before and after innovation news announcement.

The panel reports the correlation between ER0, ER3, and $\mathrm{BHAR}_{-3}, \mathrm{BHAR}_{-1}, \mathrm{BHAR}_{1}, \mathrm{BHAR}_{3}, \mathrm{BHAR}_{4}$, where the medium-horizon abnormal returns are computed by using size and industry matched control firm approach. P-values are reported in parentheses.

\begin{tabular}{|c|c|c|c|c|c|c|c|}
\hline & ER0 & ER3 & $\mathrm{BHAR}_{-3}$ & BHAR $_{-1}$ & $\mathrm{BHAR}_{1}$ & $\mathrm{BHAR}_{3}$ & $\mathrm{BHAR}_{4}$ \\
\hline ER0 & $\begin{array}{l}1.0000 \\
(0.00)\end{array}$ & $\begin{array}{l}0.8584 \\
(0.0001)\end{array}$ & $\begin{array}{l}-0.0559 \\
(0.1953)\end{array}$ & $\begin{array}{l}-0.0257 \\
(0.5515)\end{array}$ & $\begin{array}{l}-0.0220 \\
(0.6107)\end{array}$ & $\begin{array}{l}-0.0627 \\
(0.1465)\end{array}$ & $\begin{array}{l}-0.0435 \\
(0.3140)\end{array}$ \\
\hline ER3 & & $\begin{array}{l}1.0000 \\
(0.00)\end{array}$ & $\begin{array}{l}-0.0116 \\
(0.7882)\end{array}$ & $\begin{array}{l}-0.0208 \\
(0.6305)\end{array}$ & $\begin{array}{l}-0.0179 \\
(0.6790)\end{array}$ & $\begin{array}{l}0.0092 \\
(0.8311)\end{array}$ & $\begin{array}{l}-0.0147 \\
(0.7339)\end{array}$ \\
\hline $\mathrm{BHAR}_{-3}$ & & & $\begin{array}{l}1.0000 \\
(0.00)\end{array}$ & $\begin{array}{l}0.4886 \\
(0.0001)\end{array}$ & $\begin{array}{l}-0.0988 \\
(0.0218)\end{array}$ & $\begin{array}{l}-0.0147 \\
(0.73390\end{array}$ & $\begin{array}{l}0.0119 \\
(0.7823)\end{array}$ \\
\hline BHAR $_{-1}$ & & & & $\begin{array}{l}1.0000 \\
(0.00)\end{array}$ & $\begin{array}{l}-0.0425 \\
(0.3249)\end{array}$ & $\begin{array}{l}0.0007 \\
(0.9868)\end{array}$ & $\begin{array}{l}-0.0392 \\
(0.3639)\end{array}$ \\
\hline $\mathrm{BHAR}_{1}$ & & & & & $\begin{array}{l}1.0000 \\
(0.00)\end{array}$ & $\begin{array}{l}0.5313 \\
(0.0001)\end{array}$ & $\begin{array}{l}0.4399 \\
(0.0001)\end{array}$ \\
\hline $\mathrm{BHAR}_{3}$ & & & & & & $\begin{array}{l}1.0000 \\
(0.00)\end{array}$ & $\begin{array}{l}0.8582 \\
(0.0001)\end{array}$ \\
\hline $\mathrm{BHAR}_{4}$ & & & & & & & $\begin{array}{l}1.0000 \\
(0.00)\end{array}$ \\
\hline
\end{tabular}




\section{Table 5: Multivariate OLS regressions of announcement abnormal returns and medium-horizon buy-and-hold abnormal returns on various firm-specific}

characteristics

For a sample of 611 innovation news announcements made by biotech companies during 1983-1993, we calculate the one-day and three-day announcement abnormal returns (ER0 and ER3 respectively). We also use the size-and-industry match firm approach to calculate the three-month and six-month post announcement buy and hold abnormal returns $\left(\mathrm{BHAR}_{3}\right.$ and $\mathrm{BHAR}_{6}$ respectively). The independent variables are LME - log of market equity value; LBM - the log of book-to-market ratio; R\&D/asset-1;

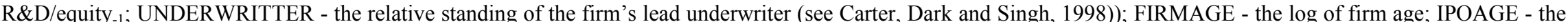
$\log$ of the year since IPO; SIZERANK, which measures which size quintile the firm is in the universe of CRSP stocks, and BMRANK, which measures which book-tomarket quintile the firm is in the CRSP universe are also used as independent variables. t-statistics based on heteroscedasticity-adjusted standard errors are in parentheses.

$*, * *, * * *$ - significant at the $10 \%, 5 \% 1 \%$ level

\begin{tabular}{|c|c|c|c|c|c|c|c|c|}
\hline Variable & [1] ER0 & [2] ER0 & [3]ER3 & [4]ER3 & [5] $\mathrm{BHAR}_{3}$ & [6] $\mathrm{BHAR}_{3}$ & {$[7] \mathrm{BHAR}_{6}$} & {$[8] \mathrm{BHAR}_{6}$} \\
\hline Intercept & $\begin{array}{l}0.0392 * \\
(1.680)\end{array}$ & $\begin{array}{l}0.0217 \\
(1.093)\end{array}$ & $\begin{array}{l}0.0571 * * \\
(2.020)\end{array}$ & $\begin{array}{l}0.0325 \\
(1.028)\end{array}$ & $\begin{array}{l}0.0207 \\
(0.217)\end{array}$ & $\begin{array}{l}0.2158^{* *} \\
(2.147)\end{array}$ & $\begin{array}{l}0.04174 \\
(0.659)\end{array}$ & $\begin{array}{l}0.2879 * \\
(1.964)\end{array}$ \\
\hline $\mathrm{R} \& \mathrm{D} /$ asset $_{-1}$ & $\begin{array}{l}0.0199 * * \\
(2.469)\end{array}$ & $\begin{array}{l}0.0169^{*} \\
(1.846)\end{array}$ & $\begin{array}{l}0.0400 * * * \\
(3.262)\end{array}$ & $\begin{array}{l}0.0412 * * * \\
(2.750)\end{array}$ & $\begin{array}{l}0.0938 * * \\
(2.237)\end{array}$ & $\begin{array}{l}0.0819^{* *} \\
(2.046)\end{array}$ & $\begin{array}{l}0.1121^{*} \\
(1.954)\end{array}$ & $\begin{array}{l}0.1417 * * \\
(2.479)\end{array}$ \\
\hline LME & & $\begin{array}{l}-0.0054^{*} \\
(-1.781)\end{array}$ & & $\begin{array}{l}-0.0059 \\
(-1.329)\end{array}$ & & $\begin{array}{l}-0.0141 \\
(-0.661)\end{array}$ & $\begin{array}{l}-0.0141 \\
(-0.498)\end{array}$ & \\
\hline LBM & & $\begin{array}{l}-0.0039 \\
(-0.949)\end{array}$ & & $\begin{array}{l}0.0064 \\
(0.097)\end{array}$ & & $\begin{array}{l}0.0352^{* *} \\
(2.116)\end{array}$ & $\begin{array}{l}0.0325^{*} \\
(1.920)\end{array}$ & \\
\hline SIZERANK & $\begin{array}{l}-0.0064^{*} \\
(-1.683)\end{array}$ & & $\begin{array}{l}-0.0092 * \\
(-1.842)\end{array}$ & & $\begin{array}{l}-0.0197 \\
(-0.959)\end{array}$ & & & $\begin{array}{l}-0.0072 \\
(-0.326)\end{array}$ \\
\hline BMRANK & $\begin{array}{l}-0.0061 \\
(-1.172)\end{array}$ & & $\begin{array}{l}-0.0037 \\
(-0.474)\end{array}$ & & $\begin{array}{l}0.03042 * \\
(1.980)\end{array}$ & & & $\begin{array}{l}0.0329 * \\
(1.977)\end{array}$ \\
\hline UNDERWRITTER & $\begin{array}{l}-0.0027 * * * \\
(-2.846)\end{array}$ & $\begin{array}{l}-0.0025 * * * \\
(-2.750)\end{array}$ & $\begin{array}{l}-0.0016 \\
(-0.979)\end{array}$ & $\begin{array}{l}-0.0053 \\
(-1.088)\end{array}$ & $\begin{array}{l}-0.00002 \\
(-0.037)\end{array}$ & $\begin{array}{l}-0.0026 \\
(-0.488)\end{array}$ & $\begin{array}{l}0.0003 \\
(0.058)\end{array}$ & $\begin{array}{l}0.0003 \\
(0.055)\end{array}$ \\
\hline FIRMAGE & $\begin{array}{l}0.0127 \\
(1.355)\end{array}$ & $\begin{array}{l}0.0151 \\
(1.440)\end{array}$ & & & & $\begin{array}{l}-0.0459 \\
(-0.925)\end{array}$ & & $\begin{array}{l}-0.0818 \\
(-1.146)\end{array}$ \\
\hline IPOAGE & & & $\begin{array}{l}0.0049 \\
(0.542)\end{array}$ & $\begin{array}{l}0.0101 \\
(0.644)\end{array}$ & $\begin{array}{l}-0.01101 \\
(-0.342)\end{array}$ & & $\begin{array}{l}-0.0438 \\
(-0.949)\end{array}$ & \\
\hline $\mathrm{N}$ & 611 & 611 & 611 & 611 & 580 & 580 & 580 & 580 \\
\hline Adjusted $\mathrm{R}^{2}$ & 0.036 & 0.033 & 0.040 & 0.038 & 0.017 & 0.021 & 0.020 & 0.021 \\
\hline
\end{tabular}


Table 6: Financial Analysts Activities around Innovation News Announcements

For the 580 firm-event observations, we search in the IBES summary database for the annual earnings forecast information. We first check whether the firm has annual earning forecast issued on the event month. Among the 580 observations, 347 of them have at least one annual earning forecast. For those 347 observations, we calculate the earning forecast error, ex post. It is defined as the difference between the median annual earning forecast and the actual earnings realization deflated by the stock price at the end of the event month. t-statistics in parentheses.

Post-event BHARs (in percent, adjusted by the returns of the size-and-industry match) for the top $30 \%$ and bottom $30 \%$ observations measured by ex post forecast error

\begin{tabular}{l|llll}
\hline & BHAR $_{1}$ & BHAR $_{2}$ & BHAR $_{3}$ & BHAR $_{6}$ \\
\hline Top 30\% & -3.91 & -5.80 & -7.21 & -11.41 \\
(Optimistic group) & $(-3.38)$ & $(-4.28)$ & $(-3.61)$ & $(-4.53)$ \\
& & & & \\
Bottom 30\% & -1.73 & -2.53 & -3.69 & -5.82 \\
(Pessimistic group) & $(-2.11)$ & $(-1.99)$ & $(-0.97)$ & $(-2.82)$ \\
& & & & \\
\hline
\end{tabular}

